\title{
Corporate foresight: developing a process model
}

\author{
Sohail Dadkhah ${ }^{1 *}$, Rohullah Bayat ${ }^{1}$, Safar Fazli ${ }^{1}$, Einallah Keshavarz Tork ${ }^{1}$ and Aboalghasem Ebrahimi ${ }^{2}$
}

\begin{abstract}
Based on previous studies on corporate foresight, companies and organizations still suffer from the lack of a framework to encounter future economic conditions as well as assuring all relevant external changes and providing proper responses. This study developed capabilities of corporate foresight and the ability for companies and organizations to utilize foresight activities successfully. The research methodology of this study was mixed. The first step of this study was to extract components to devise a proposed model. The second step of this study was to validate the proposed model quantitatively. Findings indicate that the proposed framework of the study facilitated the analysis of future scenarios and developed a strategy by incorporating foresight methodologies. Part of the strategic planning included a plan for companies to recover against discontinuous changes and yield to decrease the uncertainty of companies.
\end{abstract}

Keywords: Foresight, Corporate foresight

\section{Introduction}

Researchers indicate the explicit evidence on corporate foresight for companies and organizations still suffering from the lack of a framework to encounter future economic conditions as well as assuring all relevant external changes and providing proper responses. Many researchers have attempted to provide such framework for foresight. However, there is a lack of models for organizations and companies, and many authors including Rohrbeck and Bade [27] believe that these models are not responsive to a proper model for corporate foresight. Therefore, it is necessary to utilize foresight in corporations to encounter difficult future conditions, to forecast future trends, and to identify and interpret weak signals and entry into new markets. On the other hand, there are some barriers for the successful execution of foresight models such as future inaccessibility, changes in forecasts, contribution increases, keeping different insights, data collection, cost reduction, and needs for new methods. These barriers need to be taken into consideration to develop foresight capacities in organizations [27].

Considering the necessity of entry into global markets and the necessity of using foresight capacities to reduce

\footnotetext{
* Correspondence: sohail.dadkhah@gmail.com

${ }^{1}$ Future Studies Department, Faculty of Social Sciences, Imam Khomeini

International University, Qazvin, Iran

Full list of author information is available at the end of the article
}

existing uncertainties, recognizing/evaluating the condition to enter these markets, awareness of existing opportunities, and affecting factors on how to enter into the international market can be all practical steps in long-term planning or organizations and companies.

To enhance corporate foresight performance, it seems necessary to recognize affecting factors on corporate foresight as well as raised models in this field in order to improve corporate's capability against discontinuous changes and to design a special structured and professional framework in order to operationalize and develop corporate foresight capabilities. An approach or model should be able to combine and aggregate raised issues and acts as a key factor in assuring on-time organizational adaptability with environmental changes. Proposed model by companies is customized and utilized. On this basis, the question to which present study attempts to answer is that "which foresight model can be used for successful utilization of foresight activities in companies in order to enter global markets?"

Therefore, there is an expectation that the proposed corporate foresight model can help to decrease uncertainties of companies and can analyze future scenarios in this field and can facilitate strategy formulation process to support company's strategic decision-making by incorporating foresight methodologies and strategic planning.

For this study, it was important first to explain the fundamental research concepts. Based on provided definitions, 
there was an identification of common foresight models and frameworks. Researchers' backgrounds were taken into consideration by studying and analyzing recent researchers. Next, it was essential to address the research methodology of the study. Finally, based on explained methodology and analyses on models, theories, and previous studies, a proposed corporate foresight model is devised.

\section{Concepts and definitions}

The research title and central concepts including foresight and corporate foresight are explained below.

\section{Foresight}

Foresight is a vital issue for both public and private companies. To determine the stats of foresight in planning, one can recall Mintzberg's calcification for strategic affairs. Mintzberg has divided strategic affairs to two groups of strategic planning (with an analytical, logic, comparative, and practical approach to realize the goals) and strategic thinking (with an inspirational, creative, and test-anderror approach to transcend the borders of logic and linear thinking). On this basis, foresight removes the need for strategic planning to strategic thinking and nonlinear creativity. However, such use does not mean to limit the role of foresight to a preliminary element of strategic management; instead, foresight (future study) has (exclusive) methods and tools which leads to the recommendation, prescription, and action. FOREN ${ }^{1}$ [18] attitude on foresight is considered as the significant definition of this study. However, one should note that various definitions altogether generate a fuller perception [18].

"Foresight is a structured process which gathers insightmaking information on future in mid- and long-term horizons which targets today decisions and continuous progressive actions. Foresight emerges from the convergence of hidden trends in developing knowledge fields of policy analysis, strategic planning, and future study."

In line with this study, the definition of foresight is a process of beneficiaries by aggregating knowledge on potential factors and trends that can impact on the industry in international level. Foresight is based on in-depth attitudes toward current trends in technology, demography, laws, and lifestyles which seems to play a vital role in future development of industry, its laws, and creation of new spaces for competitiveness. There are various classifications of foresight. Since the aim of this study is not foresight typology, this study pays more attention to corporate foresight process. Only the most general classification in organizational level namely corporate foresight is identified in this study.

\section{Corporate foresight}

Due to the multidimensional definition of corporate foresight, it is hard to use foresight at the corporate level. On the corporate level, success is mainly measured by such criteria as market share increase, productivity growth, and profitability. Additionally, companies are simultaneously involved in many projects, and they pursue a different level of success. Hence, researchers in corporate level neglect high diversity of foresight activities inside the companies and, instead, they focus on foresight development projects. The relevant literature on corporate foresight defines corporate foresight through different aspects that involve a range of innovation, technology, marketing, commerce, exploring investment opportunities, and temporal turning points in organizational growth.

The historical trend of corporate foresight in the view of Rohrbeck et al. [26] (Fig. 1).

Of the most recent developments in this field, one should point out the introduction of corporate foresight as an organizational capacity and capability raised by Slaughter and developed by Rohrbeck. In his book titled Toward corporate foresight mature model, Rohrbeck [25] provided a five-element model aimed at conceptualizing organizational capability $[25,30]$. This model is a useful starting point for conceptualizing and empirical studying corporate foresight role in improving the performance of the firm. In recent years, this model is extended to a set of measurement scales and is used in different studies.

According to some scholars, corporate foresight is in the field of strategy and business economy [1]. However, others believe that corporate foresight is a part of a future study field. Future study field is used for all ranges of studies in individual, organizational, and governance levels.

According to Rohrbeck [25] who is among those connoisseurs that studied corporate foresight in the strategy field, corporate foresight is used to identify, observe, and interpret factors which stimulate changes. Corporate foresight is also utilized to determine different implications for the company and target proper reactions. Corporate foresight involves multiple stakeholders and leads into value generation through access to critical resources for superiority in competition, prepares the company for changes, and allows it to step forward desired future.

Corporate foresight increases environment conception through monitoring company's business environment and acquiring a deep vision of environmental changes and the ability to reduce uncertainty [29].

Upon reviewing the literature on future study in the most recent 30 years, Rohrbeck and Bade [27] claimed that the starting point of future study paradigm in planning the companies under uncertainty condition is the need to move from prediction to identification of multiple likely futures. Multiple futures are used to plan flexible strategies, to improve strategic agility, and to evaluate strategy establishment in strategic management researchers.

Foresight in the view of the company under the title of strategic foresight has already been conducted [31]. Strategic 


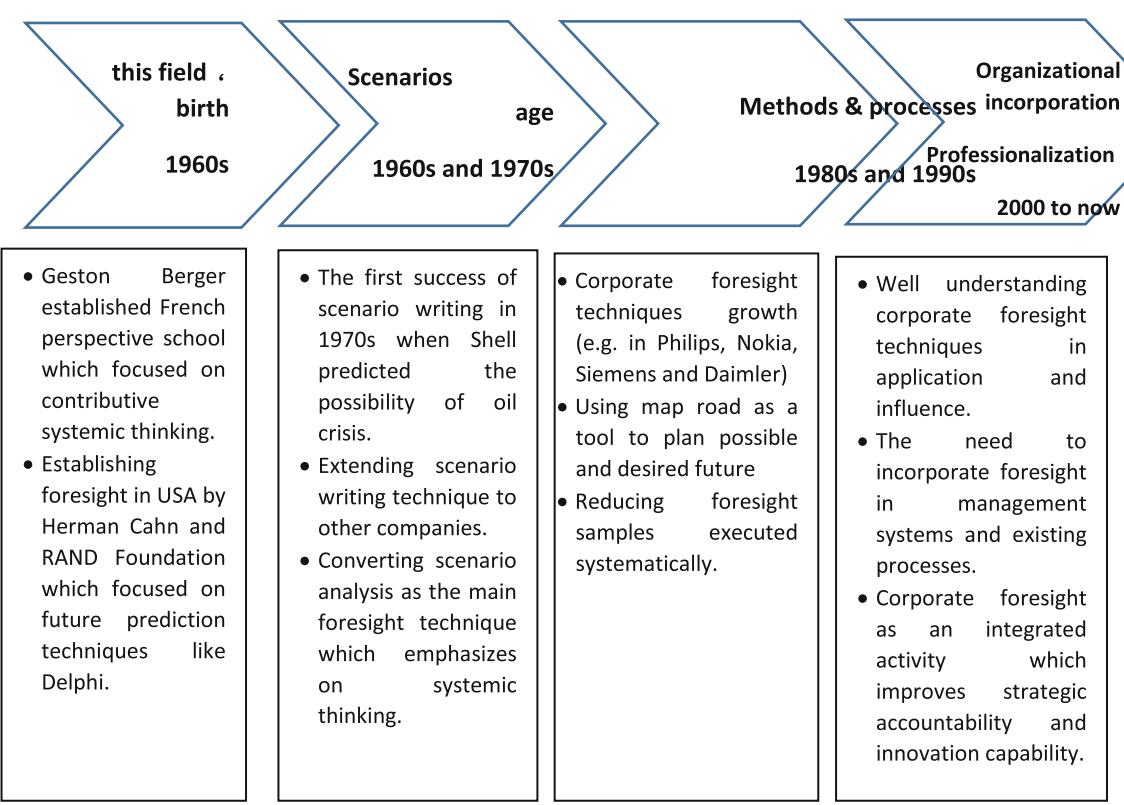

Fig. 1 The historical trend of corporate foresight in the view of Rohrbeck et al. [26]

foresight is defined by Slaughter [34] as the ability to look at future and to achieve a vision in the organization to form a strategy and to define new markets, products, and services [34].

Researchers on corporate foresight in the future study field are not mature enough, and they are mainly looking for theory building, not theory testing [25]. Hence, like another research field, there are different definitions for a field. In some definitions, organizational foresight is defined as a set of steps, activities, studies, methods, and capabilities $[1,25]$. Corporate foresight is also defined as a process [5] and even the ability of a company in future recognition [1]. Most authors have defined corporate foresight as a future study methodology aimed at identifying successful methods and processes in organizational level $[7,33]$.

Corporate foresight aims to study potential changes and to reveal what may lead to systematic or fundamental changes in next 10-25 years (or even longer). Future study is not only economic hunches, sociological analyses, or prediction on technology field but also a multidisciplinary study on changes in all main fields of life. This study aims to study those forces that impact on each other and shape corporate future.

In this study, the definition of corporate foresight by Hojland and Rohrbeck [16] is considered.

A set of methods which support exploring new businesses through identifying stimulants or change conducting factors (conception), describing the consequences of stimulants both individually and collectively (discovery) and initiatives that permit valued choices and designing services, products and market admiration (exploration).

\section{Corporate foresight capabilities}

Corporate foresight concept relates to different concepts discussed by experts. They include environmental analysis [9], weak signal [3], sense-making [8], and so on. On this basis, various advantages and capabilities are mentioned for corporate foresight including the following: the ability of identifying and interpreting environmental changes [36]; strategic management processes improvement, growing innovation capabilities, and improving organizational learning ability [28, 38]; and implementing strategic decisions [29].

These can be used in big companies and SMEs and in different economic sections. In fact, one can consider them relevant to "dynamic capabilities" introduced by Teece et al. [35].

Considering above points, one can divide these capabilities into two external (capabilities related to environmental search and analysis) and internal (capabilities related to receive information and how to use them) aspects.

\section{External aspect}

By studying references, corporate foresight is mainly seen as the process of external environmental information collection, interpretation, and utilization [17] or "future intelligence gathering process" [7]. For horizon scanning, companies use different methods provided by various experts.

Another concept emphasized in external aspect is to identify and analyze signals especially weak ones to combat unexpected events [3]. Strategic foresight is to use the capabilities of weak signals to recognize external changes in environment before encountering a crisis [3, 25]. However, one should say that talking about signals 
and resources of receiving them would not give much information about them rather they facilitate distribution of new ideas due to personal differences. According to Batsital and Tony, one should develop each external network in order to have different information resources.

\section{Internal aspect}

In the second step, companies need the capability of transferring, discovering, and utilizing environmental information and smart collection of future information from different resources. Such attitude is taken from resource-based approach which looks for achieving intra-organizational value.

While the search ability leads into increasing future-related information flow, huge amount of information is lost inside the organization in a decision-making process. Therefore, companies need organizational reliable capabilities and trends to diagnose new external information value and to attract and use information for commercial goals in order to use such resources.

In organizational learning literature, such capability was coined by Cohen and Levinthal [6] as the ability of attraction. On this basis, three attraction factors are introduced: management-positive attitude toward external resources, broad perspective, long-term thinking, and risk taking; cultural ability to share and communicate the activities and to disseminate knowledge as a strong internal source; and knowledge-based company by which employees diagnose the value of new information and how to use it.

Implementing strategic foresight can be too different in organizations. Such differences depend on environment and company's vision [8]. Therefore, various foresight maturity models are provided by authors like Rohrbeck and Grim [13, 25]. In these models, upon investigating the status the company and determining foresight, maturity can be planned in any organization differently to develop foresight capabilities.

In addition to the above two models, $7 \mathrm{~S}$ model is also provided to analyze organization's current status as well as future proposed situation and to diagnose the insufficiencies.

\section{Applied models and frameworks}

In this section, we review well-known foresight models, and then, we provide applied models and frameworks on entry into international markets. Since the primary function for management in an export company is to facilitate the entry of companies into international markets, we address this issue in the second part.

\section{Foresight models}

There are various models on foresight. However, since the aim of this research is not foresight typology and it pays more attention to corporate foresight process, the most general process models are represented here (Table 1).

\section{Studying and analyzing conducted studies in the field of corporate foresight}

This part of the study includes an identification of all conducted studies and remarkable works on the topic of corporate foresight. Based on all the points covered in this study, all previous studies on the topic of corporate foresight were taken into consideration. To validate this study, other researchers on the topic of corporate foresight were mentioned. To analyze and compare these other studies, findings were summarized based on the researcher's results and essential points (Tables 2 and 3 ).

A process approach on foresight is designed in three phases by Daft and Weick [8] including investigation, interpretation, and learning. Such learning cycle can be considered as a basis for foresight process steps provided by different authors so far.

Based on these other studies, one can say that Rohrbeck's studies since 2010 so far have paved the way for conducting corporate foresight studies. The main point in his work is to provide bi-dimensional models of corporate foresight. In fact, considering future study capacities and its combination with a unique knowledge field, foresight model is devised. Another point in his studies is to investigate the impact of corporate foresight on such fields as identifying new businesses and markets. Other mentioned researchers in background section are, among other things, the most updated and well-known researchers on corporate foresight used in the proposed model. Another critical point in these other studies was to use qualitative techniques so that most other researchers have used qualitative especially case study techniques while similar domestic studies are entirely different.

Overall, by studying corporate foresight background in detail, one can say that there is no similar work with this study's research title either internally or externally; however, Rohrbeck's studies show the highest similarity and have paved the way for conducting this research.

\section{Methodology}

Relevant components were identified upon literature review by using meta-synthesis technique and considering experts' opinions. In the next step, modeling was done by the descriptive, structural method. Ultimately and in quantitative phase, the model was validated.

\section{Research findings}

Initially, selected components on models were integrated by foresight selected components considering the successful experiences and conducted studies in 
Table 1 Foresight common models

\begin{tabular}{|c|c|c|}
\hline Author & Steps & Descriptions \\
\hline Martin [20] & Pre-foresight, foresight, post-foresight & $\begin{array}{l}\text { Pre-foresight (jobs which should be done before foresight); } \\
\text { foresight and post-foresight (foresight results execution process) }\end{array}$ \\
\hline Saritas [32] & Internal and external context & $\begin{array}{l}\text { Internal context is a combination of structures (e.g., internal } \\
\text { processes, trends, equipment, and technologies) and behaviors } \\
\text { (e.g., culture, policy, social interactions, skills, motivation, } \\
\text { capability, and management style). Also, foresight locates in } \\
\text { external context and their surrounding systems }\end{array}$ \\
\hline Miles [21] & $\begin{array}{l}\text { Pre-foresight, best utilization, creating an } \\
\text { image of future, execution, revision }\end{array}$ & \\
\hline Horton & Inputs, foresight, outputs & $\begin{array}{l}\text { In input step, existing information yield to foresight knowledge } \\
\text { generation. Acquired knowledge is translated and interpreted } \\
\text { so that a future conception is made. Finally, such conception is } \\
\text { synchronized and evaluated to create a kind of commitment } \\
\text { for action and execution in organization }\end{array}$ \\
\hline Reger [23] & $\begin{array}{l}\text { Determining information needs, selecting } \\
\text { research scope, data collection, data scanning, } \\
\text { analyzing and interpreting, preparing the decision } \\
\text { Evaluation, decision-making, executing, and implementing }\end{array}$ & \\
\hline Voros [37] & $\begin{array}{l}\text { Data collection, analysis, interpretation, output perspective } \\
\text { making, strategy formulation }\end{array}$ & Strategic general foresight process framework \\
\hline Godet [12] & Brainstorming, decision-making, operation design & A three-phase (and nine-step) process \\
\hline Developed model [10] & $\begin{array}{l}\text { Selecting the methodology and designing details, creating } \\
\text { the network of stakeholders, goal setting, choosing the } \\
\text { issue, execution and decision-making }\end{array}$ & $\begin{array}{l}\text { Execution includes (1) current knowledge gathering and analysis, } \\
\text { (2) description process on current trends and future facilities and } \\
\text { providing proposals, and (3) commitment which means to } \\
\text { disseminate proposals among stakeholders and finally, } \\
\text { formulating strategies and proposals and developing strategic } \\
\text { choices understanding among decision-makers }\end{array}$ \\
\hline Popper [22] & A nine-phase mode & $\begin{array}{l}\text { Major phases are similar to Miles' albeit nine-phase components } \\
\text { are added to foresight process; give components are on pre- } \\
\text { foresight, one component is on utilization phase, and one } \\
\text { component is on creation phase which impacts on other two } \\
\text { next phases namely action and revision }\end{array}$ \\
\hline
\end{tabular}

Table 2 Strength and weakness of foresight common models

\begin{tabular}{|c|c|c|}
\hline Model & Weakness & Strength \\
\hline Martin & $\begin{array}{l}\text { Lack of a system view on foresight, functions } \\
\text { interference, functions vagueness }\end{array}$ & Providing a process view on foresight \\
\hline Voros & $\begin{array}{l}\text { Lack of systemic view on foresight, lack of } \\
\text { attention to planning and process of foresight, } \\
\text { functions interference and vagueness }\end{array}$ & $\begin{array}{l}\text { Strategic view on foresight process, emphasis on } \\
\text { information and information aspect, emphasis } \\
\text { on feedback ring }\end{array}$ \\
\hline Horton & $\begin{array}{l}\text { Lack of systemic view on foresight, lack of } \\
\text { attention to planning and process of foresight }\end{array}$ & Attention to information value chain \\
\hline Miles & Lack of systemic view on foresight & $\begin{array}{l}\text { Continuous attention to foresight execution process, } \\
\text { attention to monitoring, managing, and evaluating } \\
\text { in all foresight execution steps }\end{array}$ \\
\hline Saritas & $\begin{array}{l}\text { Lack of attention to the importance of } \\
\text { propagating the evaluation of results }\end{array}$ & Systemic view on foresight \\
\hline Riger & $\begin{array}{l}\text { Lack of attention to the importance of } \\
\text { propagating the evaluation of results, lack of a } \\
\text { systemic view on foresight, lack of attention to } \\
\text { planning and process designing }\end{array}$ & Emphasis on foresight information aspect \\
\hline Developed model & Lack of systemic view on foresight & $\begin{array}{l}\text { Considering aspects and processes in information } \\
\text { value chain }\end{array}$ \\
\hline Godet & $\begin{array}{l}\text { Lack of systemic view and attention to } \\
\text { organization's internal capacities }\end{array}$ & More relevance to companies and organizations \\
\hline
\end{tabular}




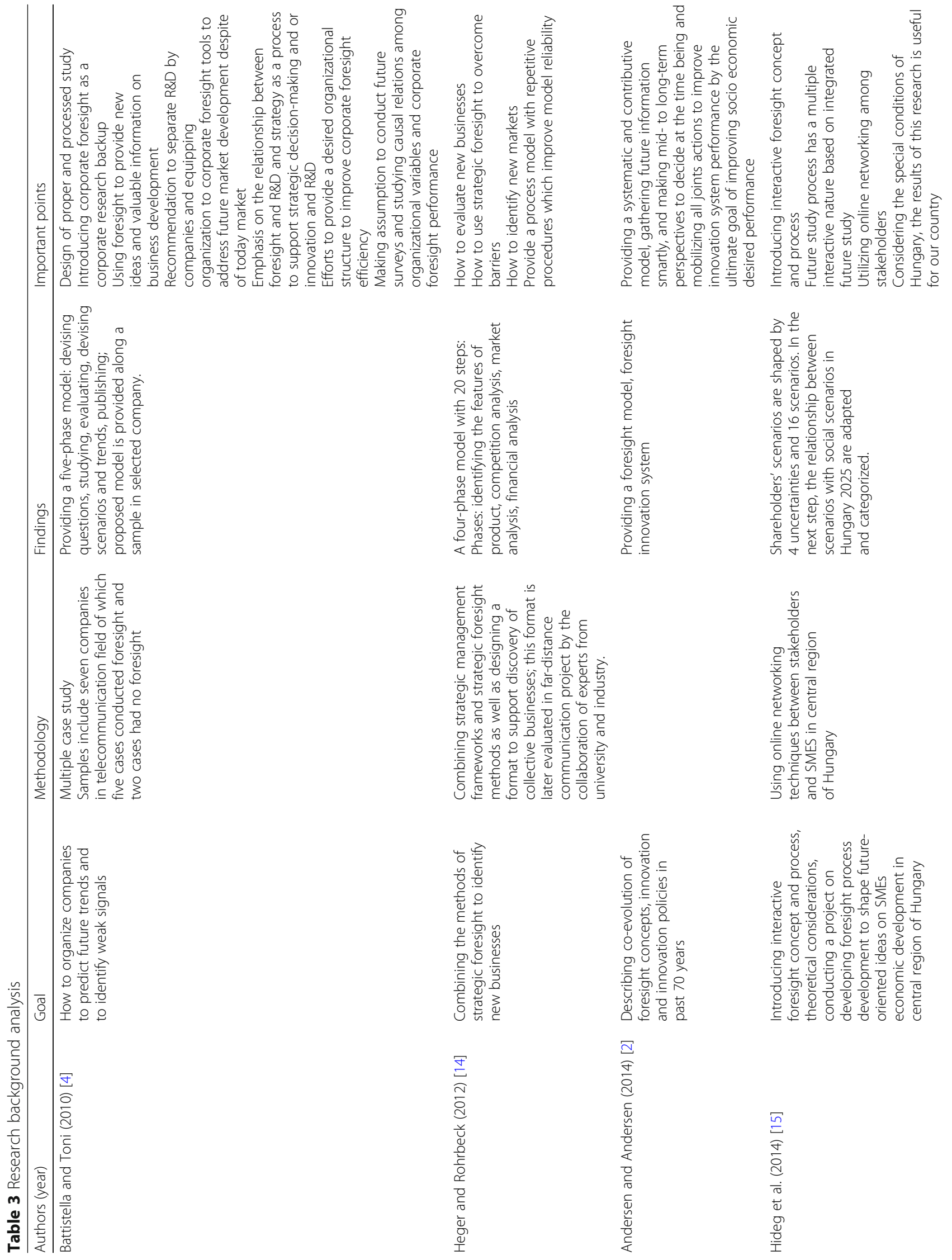




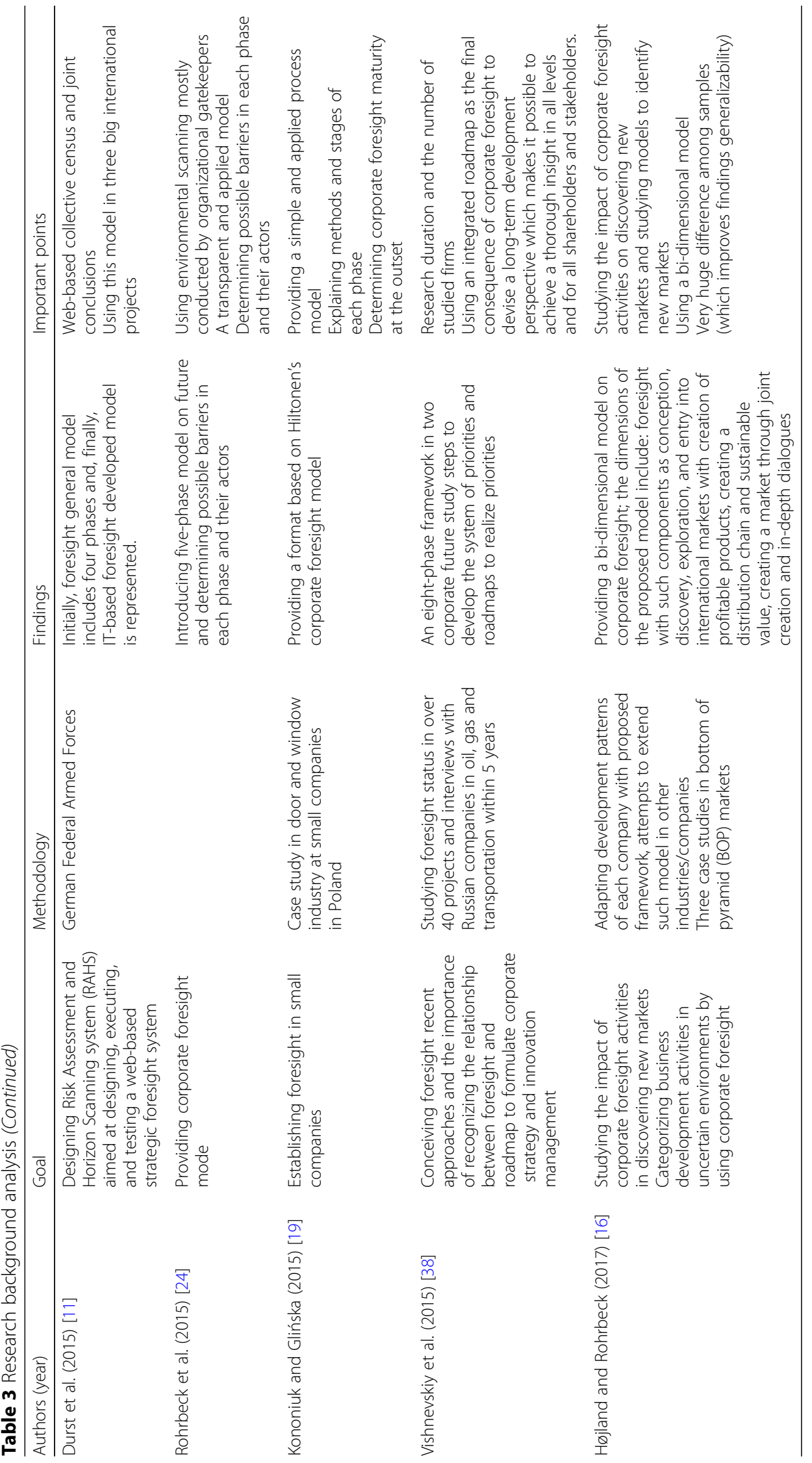


Table 4 Selected components

\begin{tabular}{|c|c|c|c|}
\hline Row & Selected components & Used models & Used researches (background) \\
\hline 1 & Determine the level of foresight maturity & - & $\begin{array}{l}\text { Rohrbeck (2010) [25] } \\
\text { Grim (2009) [13] }\end{array}$ \\
\hline 1 & Stakeholder analysis of the company & - & $\begin{array}{l}\text { Heger and Rohrbeck (2012) [14], Andersen and } \\
\text { Andersen (2014) [2], Højland and Rohrbeck (2017) [16] }\end{array}$ \\
\hline 2 & Environmental scanning & Reger, Godet & $\begin{array}{l}\text { Heger and Rohrbeck (2012) [14], Andersen and } \\
\text { Andersen (2014) [2], Højland and Rohrbeck, (2017) [16] }\end{array}$ \\
\hline 3 & Porter's competitive forces analysis & - & Kononiuk and Glińska (2015) [19] \\
\hline 4 & Identify trend and events & Godet, Martin,Voros & Heger and Rohrbeck (2012) [14], Author \\
\hline 5 & Scenario planning & Miles, Godet, Voros & $\begin{array}{l}\text { Heger and Rohrbeck (2012) [14], Andersen and } \\
\text { Andersen (2014) [2], Højland and Rohrbeck (2017) [16], } \\
\text { Kononiuk and Glińska (2015) [19], Durst et al (2015) [11], } \\
\text { Vishnevskiy et al. (2015) [38] }\end{array}$ \\
\hline 6 & Understanding critical uncertainties & Reger & Højland and Rohrbeck (2017) [16] \\
\hline 7 & Visioning & $\begin{array}{l}\text { Miles, Godet, Voros, } \\
\text { Developed model }\end{array}$ & $\begin{array}{l}\text { Heger and Rohrbeck (2012) [14], Andersen and } \\
\text { Andersen (2014) [2], Højland and Rohrbeck (2017) [16], } \\
\text { Kononiuk and Glińska (2015) [19], Durst et al. (2015) [11], } \\
\text { Vishnevskiy et al. (2015) [38] }\end{array}$ \\
\hline 8 & Determine the macro goals & Developed model & $\begin{array}{l}\text { Andersen and Andersen (2014) [2], Durst et al. (2015) [11], } \\
\text { Vishnevskiy et al. (2015) [38] }\end{array}$ \\
\hline 9 & Creating strategic options & Miles, Godet, Voros & Durst et al. (2015) [1 1], Højland and Rohrbeck (2017) [16] \\
\hline 10 & Forecasting consumer behavior & - & $\begin{array}{l}\text { Heger and Rohrbeck (2012) [14], Durst et al. (2015) [1 1], } \\
\text { Vishnevskiy et al. (2015) [38], Højland and Rohrbeck (2017) [16] }\end{array}$ \\
\hline 11 & Assessing strategic options & Reger, Godet & Durst et al. (2015) [11], Højland and Rohrbeck (2017) [16] \\
\hline 12 & Target market capacity analysis & - & Heger and Rohrbeck (2012) [14], Højland and Rohrbeck (2017) [16] \\
\hline 13 & Financial analysis & - & Heger and Rohrbeck (2012) [14] \\
\hline 14 & $\begin{array}{l}\text { Developing company marketing, HR, SCM, } \\
\text { financial strategies }\end{array}$ & Developed model & $\begin{array}{l}\text { Heger and Rohrbeck (2012) [14], Andersen and Andersen (2014) [2] } \\
\text { Durst et al. (2015) [11] }\end{array}$ \\
\hline 15 & Detecting signals & - & Ansof [3] \\
\hline 16 & $\begin{array}{l}\text { Draw up the future of the product/service } \\
\text { market alternative }\end{array}$ & - & Author \\
\hline
\end{tabular}

the corporate foresight field. Finally, this proposed corporate foresight model was developed. The combination of such components is shown below (Table 4).

Upon analyzing the elements of the different model, above components were finally extracted and their prerequisite, background, and foreground relations are determined. The role of experts is to determine such relations.

According to tables on extracted components and prerequisite relations, the proposed model is drawn below (Fig. 2).

As explained in methodology, significant elements of the proposed model are submitted, and finally, the model was validated by analyzing the questionnaires.

\section{Conclusions}

Based on corporate foresight models and theories, this study attempted to cover weaknesses of corporate foresight models and proposed a framework that combines corporate foresight and strategic planning approaches which led to the creation of new structures in companies. In macro levels, these structures address to scan international environment based on company's local advantages. A company's analytical level needs a thorough plan with corporate foresight approach to which marketing system of the company should adopt and its future markets should be devised based on this new system which puts the establishment of international environment scanning units in the first step. The execution of such step is manifested in planning and marketing system companies. The basic methodology of strategic marketing planning would yield to creation and recommendation new patterns and executive structural changes and generation of new approaches of such changes. One can name products, customers, competitors, and technology in future studies before starting conventional marketing process to recognize future transformations and company's adaptability with 


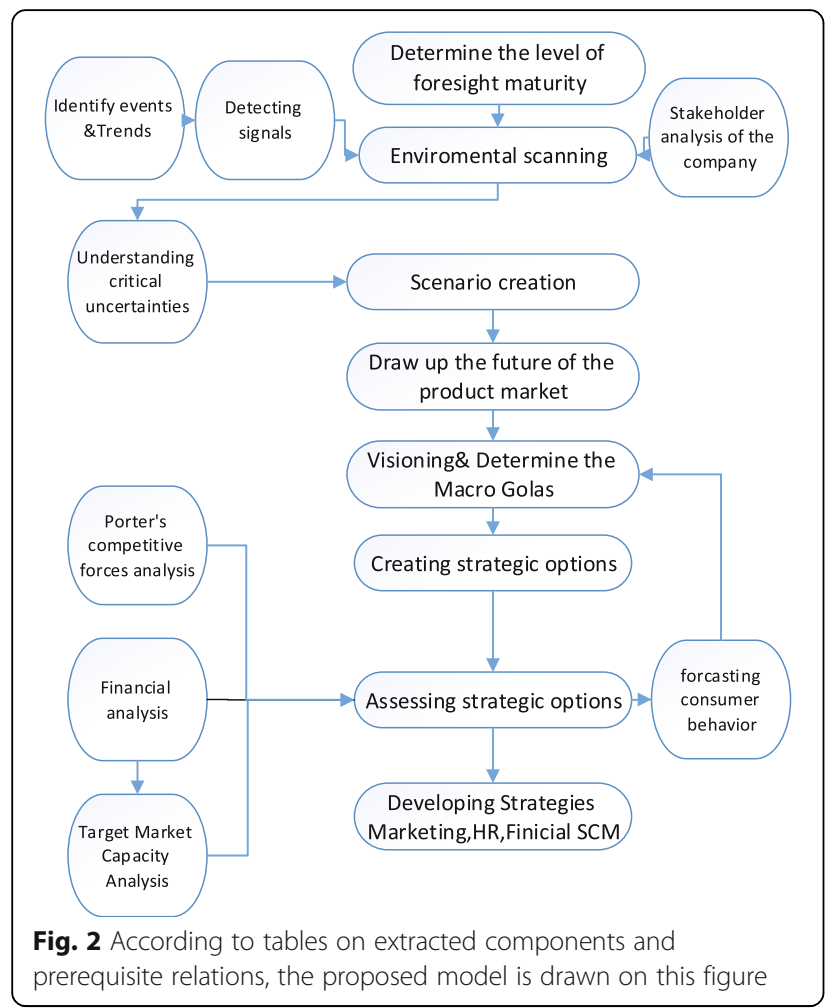

probable changes. Other concepts including organizational foresight maturity can have huge impacts on companies' performance not discussed in this study, and they should be investigated as a separated phase in future studies. Ultimately, it is predicted in this study that future corporate foresight can enjoy a more significant relationship with international marketing.

\section{Endnotes}

\section{${ }^{1}$ FOREN $=$ Foresight for Regional Development} Network

\section{Availability of data and materials}

The datasets supporting the conclusions of this article are available in the references section.

\section{Authors' contributions}

$\mathrm{SD}$ is the responsible author. RB and SF are the supervisors. EKT and $\mathrm{AE}$ are the advisors. All authors read and approved the final manuscript.

\section{Ethics approval and consent to participate}

Not applicable in this section

\section{Consent for publication}

Not applicable in this section

\section{Competing interests}

The authors declare that they have no competing interests.

\section{Publisher's Note}

Springer Nature remains neutral with regard to jurisdictional claims in published maps and institutional affiliations.

\section{Author details}

Future Studies Department, Faculty of Social Sciences, Imam Khomeini International University, Qazvin, Iran. ${ }^{2}$ Management Department, Faculty of Economic, Management and Social Sciences, Shiraz University, Shiraz, Iran.

Received: 25 April 2018 Accepted: 17 September 2018

Published online: 03 October 2018

\section{References}

1. Amsteus M (2011) Managerial foresight: measurement scale and estimation. Foresight 13(1):58-76

2. Andersen AD, Andersen PD (2014) Innovation system foresight. Technological Forecasting \& Social Change 88:276-286

3. Ansoff HI (1980) Strategic issue management. Strateg Manag J 1(2):131-148

4. Battistella, C. and Toni, A. (2010) The organization for corporate foresight: a multiple case study, in the telecommunication industry, Paper presented at the 21st Annual Conference, Vancouver, Canada, 2010. https://www. pomsmeetings.org/ConfPapers/015/015-0443.pdf

5. Becker, P. (2002) Corporate foresight in Europe: a first overview, institution for science and technology studies, Bielefeld, Germany. http://www. forschungsnetzwerk.at/downloadpub/2003_st_corporate_foresight_040109.pdf

6. Cohen, W. M., \& Levinthal, D. A. (2000) Absorptive capacity: a new perspective on learning and innovation, Strategic Learning in a Knowledge economy 39-67

7. Daheim C, Uerz G (2008) Corporate foresight in Europe: from trend-based logics to open foresight. Tech Anal Strat Manag 20(3):321-336

8. Daft RL, Weick KE (1984) Toward a model of organizations as interpretation systems. Acad Manag Rev:284-295

9. Daft RL, Sormunen J, Parks D (1988) Chief executive scanning, environmental characteristics, and company performance: an empirical study. Strateg Manag J 9(2):123-139

10. De Miranda Santo M, Coelho GM, dos Santos DM, Fellows Filho L (2006) Text mining as a valuable tool in foresight exercises: a study on nanotechnology. Technol Forecast Soc Chang 73(8):1013-1027

11. Durst C, Durst M, Kolonko T, Neef A, Greif F (2015) A holistic approach to strategic foresight: a foresight support system for the German federal armed forces. Technological Forecasting \& Social Change 97:91-104

12. Godet, M. (2001) Creating futures - scenario planning as a strategic management tool, economics, Washington

13. Grim, T. (2009) Foresight Maturity Model (FMM): achieving best practices in the foresight field. J Futures Stud 13(4):69-80

14. Heger T, Rohrbeck R (2012) Strategic foresight for collaborative exploration of new business fields. Technological Forecasting \& Social Change 79:819

15. Hideg E, Nováky E, Alács P (2014) Interactive oversight on the Hungarian SMEs. Foresight 16(4):344-359

16. Højland J, Rohrbeck R (2017) The role of corporate foresight in exploring new markets: evidence from 3 case studies in the BOP markets, technology analysis and strategic management, pp 1-13

17. Horton A (1999) A simple guide to successful foresight. Foresight 1(1):5-9

18. FOREN, A practical guide to regional foresight, 2001

19. Kononiuk A, Glińska E (2015) Foresight in a small enterprise. A case study, Procedia - Social and Behavioral Sciences, Paper presented at the 20th International Scientific Conference Economics and Management - (ICEM2015), vol 213, pp 971-976

20. Martin BR (1995) Foresight in science and technology. Tech Anal Strat Manag 7(2):139-168

21. Miles, I. (2002) Appraisal of alternative methods and procedures for producing Regional Foresight, STRATA-ETAN High-level expert group Mobilizing, the Potential Foresight Actors for and Enlarged EU

22. Popper R (2008) How are foresight methods selected? Foresight 10(6):62-89

23. Reger $G$ (2001) Technology foresight in companies: from an indicator to a network and process perspective. Tech Anal Strat Manag 13(4):533-553

24. Rohrbeck R, Thom N, Arnold H (2015a) IT tools for foresight: the integrated insight and response system of Deutsche Telekom Innovation Laboratories. Technological Forecasting \& Social Change 97:115-126

25. Rohrbeck R (2010) Corporate foresight: towards a maturity model for the future orientation of a firm. Physica-Verlag, Springer, Heidelberg and New York

26. Rohrbeck R, Battistella C, Huizingh E (2015b) Corporate foresight: an emerging field with a rich tradition. Technol Forecast Soc Chang 101:1-9

27. Rohrbeck, R., Bade, M. (2012) Environmental scanning, futures research, strategic foresight and organizational future orientation: a review, 
integration, and future research directions, presented at the annual conference (ISPIM), Barcelona, Spain

28. Rohrbeck R, Gemünden HG (2011) Corporate foresight: its three roles in enhancing the innovation capacity of a firm. Technol Forecast Soc Chang 78(2):231-243

29. Rohrbeck R, Schwarz JO (2013) The value contribution of strategic foresight: insights from an empirical study of large European companies. Technol Forecast Soc Chang 80:1593-1606

30. Rohrbeck R, Thom N, Arnold H (2015c) IT tools for foresight: the integrated insight and response system of Deutsche Telekom Innovation Laboratories. Technological Forecasting \& Social Change 97:115-126

31. Ruff $F$ (2006) Corporate foresight: integrating the future business environment into innovation and strategy, Int. J Technol Manag 34(3/4):278-295

32. Saritas, O., Taymaz, E., \& Tumer, T. (2006) Vision 2023: Turkey's National Technology Foresight Program-a contextualized description and analysis (No. 0601). ERC-Economic Research Center, Middle East Technical University

33. Schwarz JO (2009) Business war-gaming: developing foresight within a strategic simulation. Technology Analysis \& Strategic Management 21(3):291-305

34. Slaughter RA (1997) Developing and applying strategic foresight. ABN Report 5(10):13-27

35. Teece DJ, Pisano G, Shuen A (1997) Dynamic capabilities and strategic management. Strateg Manag J 18(7):509-533

36. Tsoukas H, Shepherd J (2004) Coping with the future: developing organizational foresightfulness. Futures 2(36):137-144

37. Voros J (2003) A generic foresight process framework. Foresight 5(3):10-21

38. Vishnevskiy K, Karasev O, Meissner D (2015) Integrated roadmaps and corporate foresight as tools of innovation management: the case of Russian companies. Technol Forecast Soc Chang 90:433-443

\section{Submit your manuscript to a SpringerOpen ${ }^{\circ}$ journal and benefit from:}

- Convenient online submission

- Rigorous peer review

- Open access: articles freely available online

High visibility within the field

- Retaining the copyright to your article

Submit your next manuscript at $\boldsymbol{\nabla}$ springeropen.com 